\title{
Effects of sampling and preservation on apparent feeding by chaetognaths
}

\author{
Christine T. Baier, Jennifer E. Purcell * \\ University of Maryland, Center for Environmental and Estuarine Studies, Horn Point Environmental Laboratory, PO Box 775 , \\ Cambridge, Maryland 21613, USA
}

\begin{abstract}
Chaetognaths are abundant predators of marine zooplankton. Their feeding typically has been quantified from gut contents of net-collected specimens. We evaluated the effects of mesh size and sampling duration on the gut contents of chaetognaths. Samples were compared from $333 \mu \mathrm{m}$ and $64 \mathrm{\mu m}$ mesh nets towed for $2 \mathrm{~min}$ and preserved immediately (controls), or towed for $5 \mathrm{~min}$ and preserved after $0,5,15$, or $35 \mathrm{~min}$. The $333 \mu \mathrm{m}$ mesh net undersampled small chaetognaths, resulting in different chaetognath species and length distributions and different prey compositions than those obtained from the $64 \mu \mathrm{m}$ mesh net. Prey loss from gut contents was substantial, with as much as $50 \%$ of prey lost in tows of greater than 2 min duration. Cod-end feeding, as indicated by prey in the foregut, undigested prey, and non-prey items, was much less than prey loss. Actual chaetognath predation effects may be more than double estimates made using net tow durations greater than 2 min.
\end{abstract}

KEY WORDS: Chaetognaths Predation - Zooplankton sampling methods · Cod-end feeding · Gut evacuation. Shrınkage Sagitta

\section{INTRODUCTION}

Chaetognaths are extremely abundant in marine systems, often second only to copepods in number (Feigenbaum \& Maris 1984). Copepods are the main prey of these carnivores (reviewed in Feigenbaum \& Maris 1984, Alvarino 1985, Feigenbaum 1991). Recent studies have used modifications of Bajkov's (1935) method to estimate natural feeding rates of chaetognaths from the amount of food in the guts of preserved specimens. This field-oriented approach is particularly appropriate for chaetognaths because most species are difficult to collect in good condition and to maintain in the laboratory (Feigenbaum \& Maris 1984). The accuracy of this approach depends on how well netcollected gut content samples represent in situ feeding. Bias may result if (1) samples misrepresent length or species distributions of chaetognaths and prey, (2) prey are consumed during collection (cod-end feeding), and (3) gut contents are lost during sampling and preservation.

\footnotetext{
- Addressee for correspondence

E-mail: purcell@hpel.cees.edu
}

Chaetognaths are notorious cod-end feeders (Feigenbaum \& Maris 1984); in plankton samples they are often found grasping inapproprate prey, such as large medusae or salps, or even their own tails (Feigenbaum \& Maris 1984). Sullivan (1980) found that consumption by Sagitta elegans collected in a $183 \mu \mathrm{m}$ mesh net was 10 to $50 \%$ greater than by specimens collected in a $333 \mu \mathrm{m}$ mesh net, which retained fewer prey. Methods to reduce errors due to cod-end feeding include minimizing tow duration (Szyper 1978, Øresland 1987, Kimmerer 1984), reducing prey available in the net (Newbury 1978, Feigenbaum 1979, Sullivan 1980), and excluding prey in the foregut (Alvarez-Cadena 1992, Gibbons 1992) and undigested prey from gut content analyses (Pearre 1974, Feigenbaum 1979, Sullivan 1980. Canino \& Grant 1985, Alvarez-Cadena 1993, Øresland 1995).

Although the possibility of prey loss during sampling has received little attention, some researchers have speculated that chaetognaths may evacuate their gut contents during sampling due to stress-induced regurgitation or defecation (e.g. Feigenbaum 1977, Øresland 1995). In the only previous direct test of prey loss, Szyper (1978) compared samples preserved immedi- 
ately after towing with duplicate samples preserved 20 to 30 min later, and found that the percentage of chaetognaths with food decreased with time. Preservation per se may cause chaetognaths to evacuate their guts, but this cannot be distinguished from towing effects under normal sampling procedures. Sullivan (1980) reported that she found no evidence of prey loss upon preservation.

The objective of the present study was to evaluate the effects of sampling and preservation on apparent feeding by chaetognaths. The research was done in conjunction with another study (Baier \& Purcell 1997 this issue) in which our goal was to determine the importance of chaetognaths as predators and competitors of larval fish.

\section{METHODS}

Two series of samples were collected at each of 3 stations $\left(33^{\circ} 37^{\prime} \mathrm{N}, 77^{\circ} 02^{\prime} \mathrm{W} ; 34^{\circ} 02^{\prime} \mathrm{N}, 77^{\circ} 27^{\prime} \mathrm{W} ; 34^{\circ} 28^{\prime} \mathrm{N}\right.$, $76^{\circ} 58^{\prime} \mathrm{W}$ ) in the South Atlantic Bight, off the coast of North Carolina, USA, in February 1993. Mesh sizes, towing speeds, and tow durations were chosen to correspond to the sampling program of Baier \& Purcell (1997), which used a multiple-opening-closing net (MOCNESS) fitted with $333 \mu \mathrm{m}$ mesh nets and $64 \mu \mathrm{m}$ mesh insets. Samples for the present study were collected in conical plankton nets, each fitted with a flowmeter and $1 \mathrm{l}$ hard cod-end with mesh windows. At each station, one series of tows was made with a $0.75 \mathrm{~m}$ diameter net with $333 \mu \mathrm{m}$ mesh, and one series with a $0.5 \mathrm{~m}$ net with $64 \mu \mathrm{m}$ mesh. Each series consisted of 5 surface tows, made at a speed of approximately 1.5 knots. A 'control' sample for each series was preserved in $5 \%$ formalaldehyde within 2 min after the tow began. The remaining samples were collected consecutively in $5 \mathrm{~min}$ tows. The 5 min samples were transferred undiluted to 11 containers, and each tow from a series received one of 4 treatments: preserved immediately, or held for 5,15 , or $35 \mathrm{~min}$ at ambient water temperature $\left(15.5\right.$ to $\left.18.0^{\circ} \mathrm{C}\right)$ in a water bath before preserving. These holding times correspond to durations in the cod-ends with the MOCNESS nets closed.

Subsamples were taken using a Folsom Plankton Splitter as necessary to obtain 100 to 300 chaetognaths from each sample. Chaetognaths were identified to species, and their standard lengths (distance from the front of the head to the end of the tail excluding fin) measured with a CUE-2 video image analysis program. The position of prey in the gut and the degree of digestion were recorded as in Feigenbaum (1979). Organisms protruding from the mouths of chaetognaths were identified and measured, but were not counted as gut contents. It usually was necessary to excise the gut contents using insect pins to determine the prey types and sizes. Prey size was measured as the prosome length of copepods, standard length of chaetognaths and larval fish, and total length of all other prey types.

All statistical analyses were made using Statistical Analysis Systems (SAS) software (SAS Institute Inc., Cary, NC, USA). Differences due to mesh size in chaetognath densities, and length and species distributions were examined using Analysis of Variance (ANOVA). Only the 2 min control tows were compared in these tests. The effects of sampling duration in different mesh sizes on the number of prey per chaetognath (NPC) were tested using ANOVAs. Least square means were compared using the Bonferroni approach to determine if there were differences, and the significance and direction of effects (Tarone 1990). Measures of variance were reported as \pm 1 standard error.

\section{RESULTS}

\section{Effects on size and species distributions of chaetognaths and prey}

Estimated densities, and length and species distributions of chaetognaths were affected by net mesh size. The mean density of all chaetognaths, estimated from the 2 min $64 \mu \mathrm{m}$ mesh samples pooled, was $13.5 \pm$ $13.0 \mathrm{~m}^{-3}$. Total chaetognath densities calculated from the $333 \mu \mathrm{m}$ mesh samples averaged $8.2 \pm 8.9 \mathrm{~m}^{-3}$. The difference probably resulted from small chaetognaths passing through the coarser mesh; chaetognaths smaller than $5 \mathrm{~mm}$ constituted nearly $50 \%$ of the specimens collected in the $64 \mu \mathrm{m}$ mesh net, but only $15 \%$ in the $333 \mu \mathrm{m}$ mesh samples (Fig. 1A). Chaetognath species composition also differed significantly between mesh sizes in the 2 min samples $(p<0.001$; Fig. 1B). There was a greater percentage of Sagitta enflata, one of the largest chaetognaths, in the $333 \mu \mathrm{m}$ mesh samples compared with the $64 \mu \mathrm{m}$ mesh samples, which had a higher percentage of unidentified juvenile chaetognaths $(<5 \mathrm{~mm})$.

Probably as a result of the differences in chaetognath size and species distributions, total NPCs and prey compositions differed between meshes in the 2 min samples (Fig. 2A, B). There were significantly more copepods, larvaceans, and 'other' prey in the larger chaetognaths collected by the $333 \mu \mathrm{m}$ mesh net $(p<$ $0.05)$. The smaller chaetognaths that predominated in the $64 \mu \mathrm{m}$ mesh samples ate more copepod nauplii and tintinnids. Only the 15 to $20 \mathrm{~mm}$ size category showed evidence of increased feeding in the $64 \mu \mathrm{m}$ mesh net as compared with the $333 \mu \mathrm{m}$ mesh. 


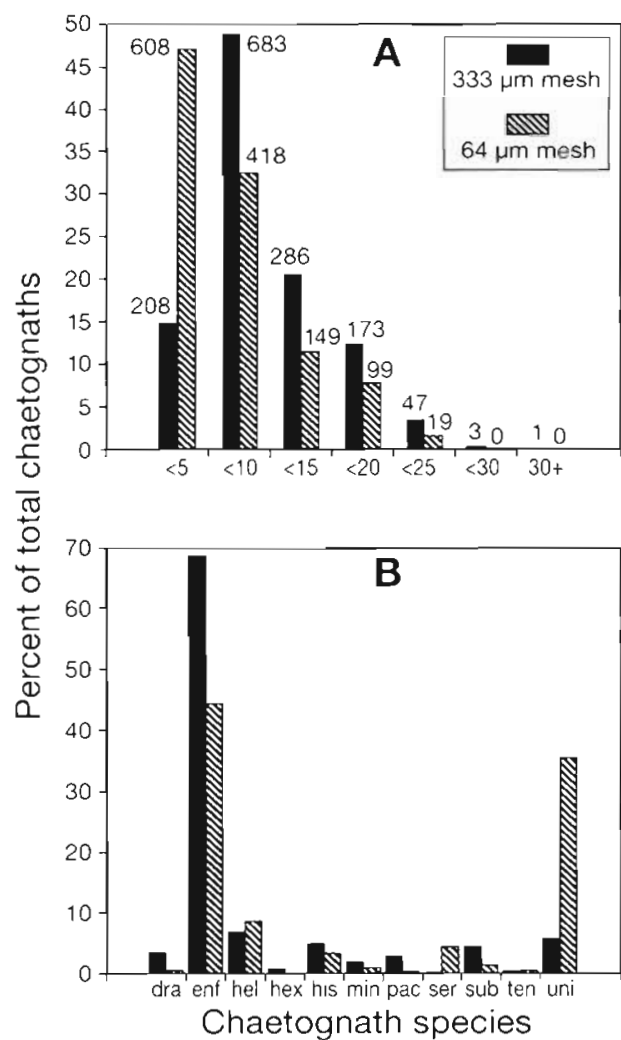

Fig. 1. (A) Comparison of length frequency distributions of chaetognaths (all species) from 2 min tows collected in $333 \mu \mathrm{m}$ and $64 \mu \mathrm{m}$ mesh nets. (B) Chaetognath species compositions from 2 min tows with $333 \mu \mathrm{m}$ and $64 \mu \mathrm{m}$ mesh nets. Numbers of chaetognaths examined are above each bar $\mathrm{dra}=$ Pterosagitta draco, enf $=$ Sagitta enflata, hel $=$ Sagitta helenae, hex = Sagitta hexaptera, his = Sagitta hispida, $\min =$ Sagitta minima, pac = Krohnitta pacifica, ser = Serratosagitta serratodentata, sub $=$ Krohnitta subtilis, ten $=$ Sagitta tenuis, and uni $=$ unidentified

\section{Changes in chaetognath gut contents during sampling}

Cod-end feeding. Cod-end feeding, as indicated by prey in the foregut, undigested prey, and non-prey items in chaetognath guts, differed among species and was affected by mesh size. In the 2 min samples, Sagitta enflata had much larger percentages (12\% and $26 \%$ in the 333 and $64 \mu \mathrm{m}$ mesh nets, respectively; Fig. 3) of prey in the foregut than Sagitta helenae $(0 \%$ in both nets). For $S$. enflata, the maximum percentage of prey in the foregut ( $34 \%$ ) occurred later (at $10 \mathrm{~min}$ ) in the $333 \mu \mathrm{m}$ mesh net than in the $64 \mu \mathrm{m}$ mesh net ( $32 \%$ at $5 \mathrm{~min}$ ) (Fig. 3). Non-prey items, including algal clumps and sand grains, were found infrequently in chaetognath guts from the $333 \mu \mathrm{m}$ mesh net, most likely because the large mesh did not retain such debris. The numbers of non-prey items in chaetognath guts changed erratically with duration in the $64 \mu \mathrm{m}$ mesh samples, accounting for 0 to $12 \%$ of total prey.

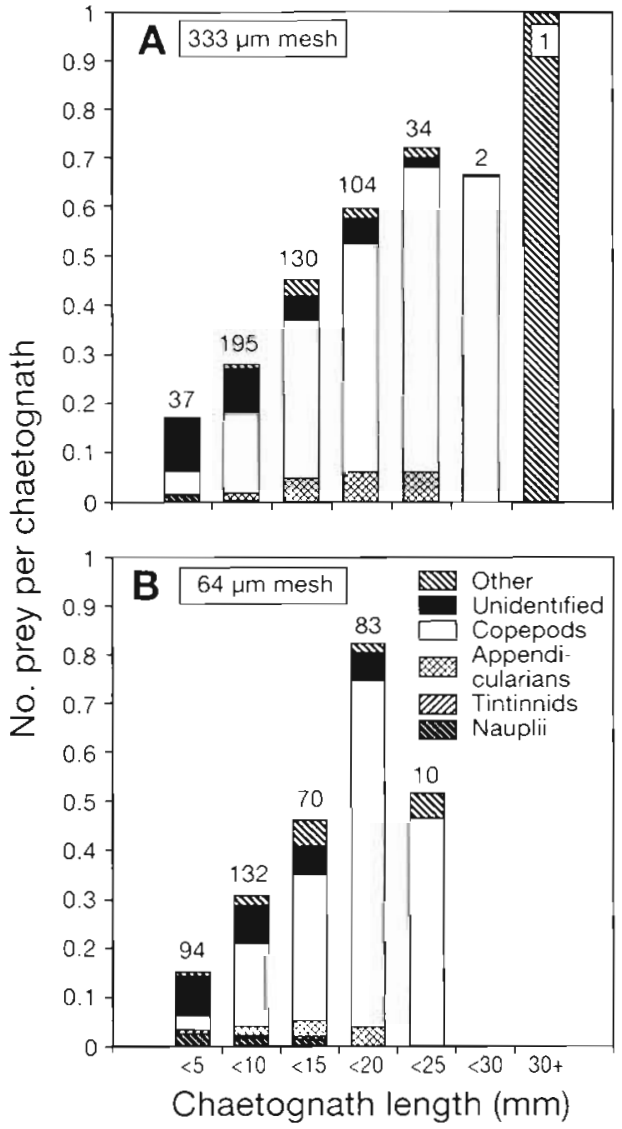

Fig. 2. NPC of prey taxa, by chaetognath length group, in (A) $333 \mu \mathrm{m}$, and (B) $64 \mu \mathrm{m}$ mesh net samples collected in 2 min tows. Numbers of prey examined are above each bar. Numbers of chaetognaths shown in Fig. $1 \mathrm{~A}$

Prey loss. The NPC was markedly lower in samples kept in the cod-end from 5 to 40 min compared with samples from 2 min tows (Fig. 4). The amount of prey lost depended on the mesh size and chaetognath species (Table 1). In the $333 \mu \mathrm{m}$ mesh samples, the NPC

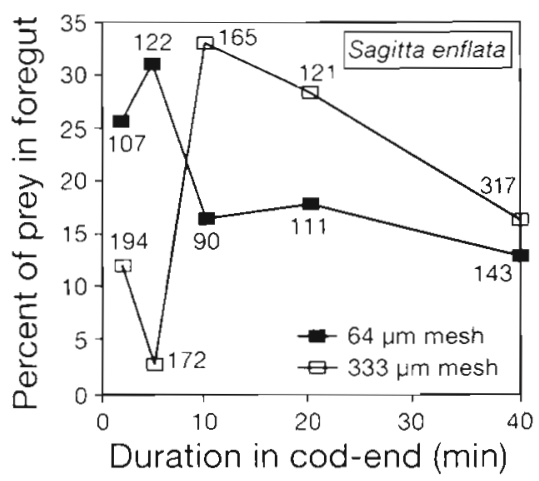

Fig. 3. Effects of duration in the cod-end on the percentages of total prey in the foregut of Sagitta enflata collected with $333 \mu \mathrm{m}$ and $64 \mu \mathrm{m}$ mesh nets. Total numbers of prey examined are shown by each point 


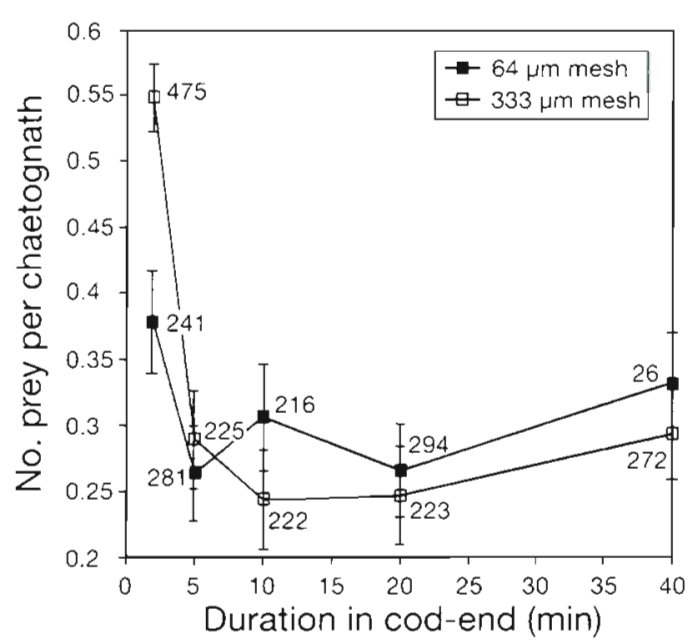

Fig. 4. Mean number of prey per chaetognath \pm 1 SE in relation to duration in the cod-end (time from beginning the tow to preservation) for all species combined from samples collected in $333 \mu \mathrm{m}$ and $64 \mu \mathrm{m}$ mesh nets. Numbers of chaetognaths examined are beside each mean

was reduced by about $50 \%$ in 5 min tows as compared with 2 min tows ( $p<0.01$; Table 1, Fig. 4 ). There were no significant differences among the 5 min tows for any holding time. In the $64 \mu \mathrm{m}$ mesh net, there were no significant differences among any sampling durations.

\section{DISCUSSION}

The methods of sampling and analysis have varied substantially among studies that quantified feeding by chaetognaths (Table 2). Chaetognaths frequently have been studied from samples taken for other purposes, and therefore tow durations and mesh sizes often have been inappropriate. Criteria used to distinguish prey

Table 1 Results of analysis of variance to test for effects of duration in the cod-end ( 2 vs 5, 10, 20, and $40 \mathrm{~min}$ ) on the number of prey per chaetognath (NPC). $\mathrm{N}=$ the number of chaetognaths exammed. $F=$ calculated $F$-statistic.

$$
\text { ' } p<0.05, \cdots p<0.01, \cdots p<0.001
$$

\begin{tabular}{|lrrrrrrr|}
\hline \multirow{2}{*}{$\begin{array}{l}\text { Chaetognath } \\
\text { species }\end{array}$} & \multicolumn{3}{c}{ All samples } & \multicolumn{3}{c|}{$64 \mu \mathrm{m}$ mesh } & \multicolumn{2}{c|}{$333 \mu \mathrm{m}$ mesh } \\
& $\mathrm{N}$ & $F$ & $\mathrm{~N}$ & $F$ & $\mathrm{~N}$ & $F$ \\
\hline All species & 2710 & $18.02 \cdots$ & 1293 & 1.70 & 1417 & $20.02 \cdots$ \\
Sagitta enflata & 1542 & $8.20 \cdots$ & 573 & 1.54 & 969 & $14.35 \cdots$ \\
Unidentified & 541 & $9.59 \cdots$ & 458 & $6.89 \cdots$ & 82 & 3.42 \\
S. helenae & 209 & 1.53 & 112 & 1.08 & 97 & 0.76 \\
Serratosagitta serratodentata & 121 & $4.09 \cdots$ & 58 & 1.83 & 63 & $2.82 \cdot$ \\
S. hispida & 112 & 0.92 & 43 & 0.35 & 69 & 1.53 \\
Pterosagitta draco & 56 & 2.55 & 8 & 0.38 & 48 & 2.92 \\
S. minima & 54 & 1.51 & 13 & 0.37 & 41 & 1.93 \\
Krohnitta sp. & 53 & 1.97 & 23 & 2.17 & 30 & 0.68 \\
S. hexaptera & 27 & 4.19 & 0 & - & 27 & 4.19 \\
S. tenuis & 12 & 0.95 & 6 & 0.54 & 6 & 0.44 \\
& & & & & & & \\
\hline
\end{tabular}

consumed in the cod-end from 'natural' prey also have varied among studies.

Understanding how sampling procedures affect chaetognaths is critical both for interpreting previous work and for improving future studies. Prior to our study, the only information available on the effects of sampling on chaetognath gut contents was provided by the observations of Szyper (1978) and Sullivan (1980). Unfortunately, actual sampling conditions could not be perfectly simulated in our study. Chaetognaths could be subject to more stress in a net being towed than in the stationary cod-ends used in our experiments. Also, the control tows, especially those made with the $64 \mu \mathrm{m}$ mesh net, still subjected the chaetognaths to agitation and crowding. Therefore, we believe that our estimates of sampling effects are conservative.

Although researchers have expressed much concern about feeding by chaetognaths during collection in nets, the most notable effect observed in this study was a significant loss of prey. The sudden decrease $(50 \%)$ in the NPC between 2 min and 5 min samples from the $333 \mu \mathrm{m}$ mesh net indicates that prey loss was due more to stress-induced gut evacuation than to continued digestion of prey. Szyper (1978) found that Sagitta enflata with prey decreased by as much as $80 \%$ in samples held for 20 to $30 \mathrm{~min}$. In the 2 studies in which $S$. enflata were collected in tows of $<2 \mathrm{~min}$ (Szyper 1978, Kimmerer 1984), the NPCs were much higher than in any other studies (Table 2).

Although the $333 \mu \mathrm{m}$ mesh undersampled small chaetognath populations, it may have represented in situ feeding better than the $64 \mu \mathrm{m}$ mesh samples. Chaetognaths may evacuate their gut contents after a relatively short duration in the $64 \mu \mathrm{m}$ mesh nets, because the cod-end quickly becomes crowded with small organisms. The $333 \mu \mathrm{m}$ mesh net filtered 135.8 $\pm 14.6 \mathrm{~m}^{3}$ in $5 \mathrm{~min}$, compared with $60.2 \pm 13.1$ in 2 min. The $64 \mu \mathrm{m}$ mesh net apparently clogged within $2 \mathrm{~min}$, filtering no more water in $5 \mathrm{~min}\left(24.6 \pm 5.8 \mathrm{~m}^{3}\right)$ than in 2 min $(29.8 \pm 29.0)$. Cod-end feeding also may begin sooner in response to increased prey concentrations in the $64 \mu \mathrm{m}$ mesh than in the $333 \mu \mathrm{m}$ mesh net. This may explain the relatively high proportions of prey in the foregut seen in the 2 and 5 min samples from the $64 \mu \mathrm{m}$ mesh net. In the $333 \mu \mathrm{m}$ mesh net, the sudden increase in the proportion of prey in the foregut at 10 min suggests a lag period before the cod-end became crowded enough to provoke chaetognaths to feed.

It is clear that both prey loss and codend feeding occur; prey loss appears 
Table 2. Summary from the literature of sampling methods and estimates of chaetognath feeding lonly studies giving tow duration are included). Total duration is from the beginning of the tow to preservation. NPC: number of prey per chaetognath; FR: feeding rate in number of prey chaetognath-1 $\mathrm{d}^{-1} \mathrm{MOC}$ indicates that Multiple-Opening-Closing nets were used and sampling duration varied with each net but was not reported. $N$ : net modified to exclude prey; F: prey in the foregut excluded from the analysis; $D$ : prey in the early stages of digestion excluded from the analysis. All samples were preserved in formalin

\begin{tabular}{|c|c|c|c|c|c|c|c|c|}
\hline Species & $\begin{array}{l}\text { Temp. } \\
\left({ }^{\circ} \mathrm{C}\right)\end{array}$ & $\begin{array}{l}\text { Mesh } \\
(\mu \mathrm{m})\end{array}$ & $\begin{array}{l}\text { Duratio } \\
\text { Tow }\end{array}$ & $\begin{array}{l}n(\min ) \\
\text { Total }\end{array}$ & $\begin{array}{l}\text { Modifica- } \\
\text { tions }\end{array}$ & NPC & $\mathrm{FR}$ & Source \\
\hline Sagitta enflata & $\begin{array}{l}- \\
24-26 \\
- \\
18 \\
18\end{array}$ & $\begin{array}{c}330 \\
330 \\
1620 \\
333 \\
333\end{array}$ & $\begin{array}{l}- \\
- \\
- \\
- \\
-\end{array}$ & $\begin{aligned} & <1 \\
& <2 \\
15 & -30 \\
& <2 \\
& \geq 5\end{aligned}$ & $\begin{array}{c}\mathrm{F} \\
- \\
\mathrm{NFD} \\
\mathrm{F} \\
\mathrm{F}\end{array}$ & $\begin{array}{l}1.09-1.18 \\
1.04 \\
0.30 \\
0.54 \\
0.26\end{array}$ & $\begin{array}{c}7.3-11.6 \\
7.4 \\
2.2 \\
- \\
-\end{array}$ & $\begin{array}{l}\text { Kimmerer (1984) } \\
\text { Szyper (1978) } \\
\text { Feigenbaum (1979) } \\
\text { This study } \\
\text { This study }\end{array}$ \\
\hline S. elegans & $\begin{array}{l}4-8 \\
6 \\
- \\
-1\end{array}$ & $\begin{array}{l}333 / 183 \\
450 \\
335 \\
375^{\mathrm{d}}\end{array}$ & $\begin{array}{c}10 \\
10-15 \\
15 \\
1\end{array}$ & $\begin{array}{l}- \\
- \\
- \\
-\end{array}$ & $\begin{array}{l}\mathrm{D} \\
N \\
\mathrm{ND} \\
-\end{array}$ & $\begin{array}{l}0.04-0.41 \\
0.06-0.28 \\
0.09-0.54 \\
0.00-0.76\end{array}$ & $\begin{array}{c}- \\
0.2-1.0 \\
0.8-3.6 \\
0.3-1.1\end{array}$ & $\begin{array}{l}\text { Sullivan (1980) } \\
\text { Øresland (1987) } \\
\text { Alvarez-Cadena (1993) } \\
\text { Falkenhaug (1991) }\end{array}$ \\
\hline S. setosa & 6 & $\begin{array}{l}450 \\
333\end{array}$ & $\begin{array}{c}10-15 \\
15\end{array}$ & $\begin{array}{l}- \\
-\end{array}$ & $\begin{array}{l}N \\
D\end{array}$ & $\begin{array}{l}0.29-0.25 \\
0.14-0.38\end{array}$ & $\begin{array}{c}2.3 \\
1.4-5.4\end{array}$ & $\begin{array}{l}\text { Oresland (1987) } \\
\text { Alvarez-Cadena (1992) }\end{array}$ \\
\hline Eukrohnia hamata & $\begin{array}{c}- \\
4-8 \\
-2-1\end{array}$ & $\begin{array}{c}300 \\
333 / 183 \\
110 / 130 / 333\end{array}$ & $\begin{array}{c}25-50 \\
10 \\
-\end{array}$ & $\begin{array}{c}- \\
- \\
3-25\end{array}$ & $\begin{array}{c}- \\
D \\
F D\end{array}$ & $\begin{array}{c}0.10-0.36 \\
0.10 \\
0.8-0.12\end{array}$ & $\begin{array}{c}0.3-1.1 \\
- \\
0.3-0.5\end{array}$ & $\begin{array}{l}\text { Øresland (1990) } \\
\text { Sullivan (1980) } \\
\text { Øresland (1995) }\end{array}$ \\
\hline Pterosagitta draco & $12-25$ & $202 / 183$ & - & 30 & $N$ & $0.10-0.12$ & 1.0 & Newbury (1978) \\
\hline S. friderici & - & 200 & - & $\mathrm{MOC}$ & - & 0.08 & 0.5 & Stuart \& Verheye (1991) \\
\hline $\begin{array}{l}\text { Serratosagitta } \\
\text { serratodentata }\end{array}$ & - & 200 & - & MOC & F & $0.0-1.0$ & - & Gibbons (1992) \\
\hline S. tenuis & $21-25$ & $333 / 202$ & $5-10$ & - & D & $0.09-0.45$ & $3.1-8.7$ & Canino \& Grant (1985) \\
\hline
\end{tabular}

to occur initially and cod-end feeding may continue throughout the tow. These problems probably are most effectively minimized by sampling chaetognaths in very brief (<2 min), gentle tows. Sullivan's (1980) method of quantifying small chaetognaths from a fine mesh inset and analysing gut contents of chaetognaths from a coarser mesh net may be the best compromise to deal with the respective shortcomings of fine and coarse mesh nets.

When these measures are not possible, some adjustments based on the results of our study may be applicable. In samples towed longer than $5 \mathrm{~min}$ with a $333 \mu \mathrm{m}$ mesh net, NPC decreased by about $50 \%$. The decrease in NPC was not significant for the $64 \mu \mathrm{m}$ mesh net samples, but perhaps that was because the NPC had begun to decrease within the 2 min duration of the control tows. Therefore, these adjustments may be appropriate for fine mesh as well as large mesh.

Our results suggest that excluding prey in the foregut from gut content analysis was appropriate for the species and temperatures involved in this study; however, this measure is probably effective only in combination with very short tows. Szyper (1978) noted that the percent of prey in the foregut was a poor indicator of codend feeding, due to the rapid transfer (0.5 to $2 \mathrm{~min})$ of food to the rear gut of Sagitta enflata at temperatures of 24 to $26^{\circ} \mathrm{C}$. Reeve et al. (1975) also observed rapid movement of prey to the rear gut in Sagitta hispida.
Factors such as temperature and species differences may be important in determining how much and how quickly cod-end feeding and prey loss occur. Therefore, the effects seen in this study would not apply to all species or in all environments. Also, other sources of error, such as experimentally determined digestion rates, may introduce substantial error into feeding rate calculations. The results of our study clearly showed that apparent feeding of chaetognaths is affected by the sampling methods used. Prey loss during sampling, which had received little attention previously, was of greater magnitude than cod-end feeding. The importance of chaetognaths as predators in marine food webs may have been underestimated by half in most studies due to the net sampling methods employed.

Acknowledgements. We thank Don Hoss, Jeff Govoni, Larry Settles and Dave Peters for logistical support on the cruises. We are grateful to Dave Nemazie for help with sampling, George Grant for verifying chaetognath species identifications, and Dan Jacobs for statistical advice. Ed Houde, Larry Sanford, and John Petersen provided many helpful comments on the manuscript. This research was part of the South Atlantic Bight Recruitment Experiment, which is sponsored by the NOAA Coastal Ocean Program's Coastal Fisheries Ecosystems project, and was funded through grant NA26RG0413 from the Maryland Sea Grant Program. Additional funding was provided by the Horn Point Environmental Laboratory. UMCEES Contribution No. 2783. 


\section{LITERATURE CITED}

Alvarez-Cadena JN (1992) Feeding habits, gonadic stages and size frequency distribution of Sagitta setosa J. Muller to the east of the Isle of Man, North Irish Sea. An del Inst Cienc del Mar y Limnol Univ Nal Quton Mexico 19:215-222

Alvarez-Cadena JN (1993) Feeding of the chaetognath Sagitta elegans Verrill. Estuar Coast Shelf Sci 36:195-206

Alvarino A (1985) Predation in the plankton realm; mainly with reference to fish larvae. Inv Mar CICIMAR 2:1-122

Baier CT, Purcell JE (1997) Trophic interactions of chaetognaths, larval fish and zooplankton in the South Atlantic Bight. Mar Ecol Prog Ser 146:43-53

Bajkov AD (1935) How to estimate the daily food consumption of fish under natural conditions. Trans Am Fish Soc 65: $288-289$

Canino MF, Grant GC (1985) The feeding and diet of Sagitta tenuis (Chaetognatha) in the lower Chesapeake Bay. J Plankton Res 7:175-188

Falkenhaug $T$ (1991) Prey composition and feeding rate of Sagitta elegans var. arctica (Chaetognatha) in the Barents Sea in early summer. In: Sakshaug E, Hopkins CCE, Oritsland NA (eds) Proceedings of the Pro Mare Symposium on Polar Marine Ecology, Trondheim, 12-16 May 1990

Feigenbaum D (1977) Nutritional ecology of the Chaetognatha with particular reference to external hair patterns. PhD Dissertation, University of Miami

Feigenbaum D (1979) Daily ration and specific daily ration of the chaetognath Sagitta enflata. Mar Biol 54:75-82

Feigenbaum D (1991) Food and feeding behavior. In: Bone Q, Kapp H, Pierrot-Bults AC (eds) The biology of chaetognaths. Oxford University Press, New York, p 45-54

Feigenbaum DL, Maris RC (1984) Feeding in the Chaetognatha. Oceanogr Mar Biol Ann Rev 22:343-392

Gibbons MJ (1992) Diel feeding and vertical migration of

This article was presented by K. Sherman (Senior Editorial Advisor), Narragansett, Rhode Island, USA
Sagitta serratodentata Krohn tasmanica (Chaetognatha) in the southern Benguela. J Plankton Res 14:249-259

Kimmerer WJ (1984) Selective predation and its impact on prey of Sagitta enflata (Chaetognatha). Mar Ecol Prog Ser 15:55-62

Newbury TK (1978) Consumption and growth rates of chaetognaths and copepods in subtropical oceanic waters. Pacif Sci 32:61-78

Øresland V (1987) Feeding of the chaetognaths Sagitta elegans and $S$. setosa at different seasons in Gullmarsfjorden, Sweden. Mar Ecol Prog Ser 39:69-79

Øresland V (1990) Feeding and predation impact of the chaetognath Eukrohnia hamata in Gerlache Strait, Antarctic Peninsula. Mar Ecol Prog Ser 63:201-209

Øresland V (1995) Winter population structure and feeding of the chaetognath Eukrohnia hamata and the copepod Euchaeta antarctica in Gerlache Strait, Antarctic Peninsula. Mar Ecol Prog Ser 119:77-86

Pearre S Jr (1974) Ecological studies of three West-Mediterranean chaetognaths. Invest Pesq 38:325-369

Reeve MR, Cosper TC, Walter MA (1975) Visual observations on the process of digestion and the production of faecal pellets in the chaetognath Sagitta hispida Conant. J Exp Mar Biol Ecol 17:39-46

Stuart V, Verheye HM (1991) Diel migration and feeding patterns of the chaetognath. Sagitta friderici, of the west coast of South Africa. J Mar Res 49:493-515

Sullivan BK (1980) In situ feeding behavior of Sagitta elegans and Eukrohnia hamata (Chaetognatha) in relation to the vertical distribution and abundance of prey at Ocean Station ' $\mathrm{P}$ '. Limnol Oceanogr 25:317-326

Szyper JP (1978) Feeding rate of the chaetognath Sagitta enflata in nature. Estuar Coast Mar Sci 7:567-373

Tarone RE (1990) A modified Bonferroni method for discrete data. Biometrics 46:515-522

Manuscript first received: November 5, 1995

Revised version accepted: November 11, 1996 